\title{
Enhancement of Immunoglobulin M Production in B Cells by the Extract of Red Bell Pepper
}

\author{
Tomomi Goto, Md. Moklesur Rahman Sarker, Ming Zhong, Satoshi Tanaka, \\ and Eiichi Gohda* \\ Department of Immunochemistry, Division of Pharmaceutical Sciences, Okayama University Graduate School of Medicine, Dentistry \\ and Pharmaceutical Sciences, 1-1-1 Tsushima-naka, Kita-ku, Okayama 700-8530, Japan
}

(Received January 10, 2010; Accepted February 13, 2010; Published online February 22, 2010)

\begin{abstract}
Under immunocompromised conditions such as aging, cancer, diabetes, burns, and sepsis, external agents may be useful for upregulation of the immune system to prevent infection. Dietary products have the advantage of being safe and easy to take. An extract of red bell pepper (Capsicum апnиит L.) flesh markedly enhanced immunoglobulin $\mathrm{M}(\mathrm{IgM})$ production by murine B cells and their proliferation. The effect of the extract on IgM production was not abrogated by treatment with polymyxin B and was also observed in spleen cells of lipopolysaccharideunresponsive $\mathrm{C} 3 \mathrm{H} / \mathrm{HeJ}$ mice. Treatment of $\mathrm{B}$ cells with the extract resulted in an increase in the number of IgMsecreting cells and cluster of differentiation (CD)138-positive cells. The IgM production-enhancing activity was resistant to trypsin treatment but was heat-labile. The activity was eluted in a peak with a molecular weight of 6000 on gel filtration. These results demonstrated that the extract of red bell pepper enhanced IgM production in B cells and suggest that the active substance(s) in the extract is a non-proteinous heat-labile macromolecule.
\end{abstract}

Key words_— red bell pepper extract, B cell, immunoglobulin M production, differentiation, proliferation

\section{INTRODUCTION}

The immune system plays an important role not only in defense against infection by bacteria, viruses and other parasites but also in identifying and eliminating tumors. However, there are many immunosuppressing factors in our daily lives. The function of the immune system can decline with age and in patients with cancer, diabetes, burns, and sepsis. ${ }^{1,2)}$ Immunity is also suppressed by ultraviolet radiation and stress. ${ }^{3)}$ Moreover, immunosuppression is one of the commonly encountered side effects in patients receiving chemotherapy and radiotherapy. Under those immunocompromised conditions, external agents may be useful for upregulation of the immune system to prevent infection.

Bell peppers (Capsicum annuum L.), also

\footnotetext{
*To whom correspondence should be addressed: Department of Immunochemistry, Division of Pharmaceutical Sciences, Okayama University Graduate School of Medicine, Dentistry and Pharmaceutical Sciences, 1-1-1 Tsushima-naka, Kita-ku, Okayama 700-8530, Japan. Tel.: +81-86-251-7960; Fax: +81-86-251-7926; E-mail: gohda@pheasant.pharm.okayamau.ac.jp
}

known as sweet peppers, are cultivated throughout the world for use as a vegetable. When bell peppers are fully ripe, the color changes from green to yellow, orange, red or purple depending on the cultivar. The fruits of bell peppers contain vitamin C, provitamin $\mathrm{A}$ and other antioxidants such as flavonoids and hydroxycinnamic derivatives. ${ }^{4}$ Recent studies on pharmacological properties of bell pepper extracts and their constituents have shown several biological activities including antimutagenic, anticancer, and anti-inflammatory activities. ${ }^{5-7)}$

Since dietary products have the advantage of being safe and easy to take, we have investigated immunostimulating activities in crude extracts of various vegetables and fruits. In this study we found that the extract of red bell pepper flesh potently promoted polyclonal immunoglobulin M (IgM) production by murine $\mathrm{B}$ cells.

\section{MATERIALS AND METHODS}

Materials — Purified mouse IgM, goat antimouse IgM antibody $(\mathrm{Ab})$, and horseradish per- 
oxidase (HRP)-conjugated goat anti-mouse $\operatorname{IgM}$ $\mathrm{Ab}$ were obtained from Zymed Laboratories Inc. (San Francisco, CA, U.S.A.), Organon Teknika Corporation (Durham, NC, U.S.A.), and Kirkegaad \& Perry Laboratories (Gaithersburg, MD, U.S.A.), respectively. Phycoerythrin (PE)-conjugated rat anti-mouse cluster of differentiation (CD)138 (syndecan-1) and anti-mouse CD16/CD32 monoclonal Abs (mAbs) were purchased from BD Biosciences Pharmingen (San Jose, CA, U.S.A.). [6$\left.{ }^{3} \mathrm{H}\right]$ Thymidine was obtained from GE Healthcare Bio-Sciences Corp. (Little Chalfont, U.K.).

Preparation of Red Bell Pepper Extract Freeze-dried powder of the flesh of red bell pepper (607A), cultivated in Miyazaki Agricultural Research Institute (Miyazaki, Japan), was donated by Miyazaki Prefectural Food R\&D Center (Miyazaki, Japan). The powder was mixed with 10 volumes of phosphate-buffered saline (PBS) for $1.5 \mathrm{hr}$ under continuous stirring at $40^{\circ} \mathrm{C}$ followed by centrifugation. The supernatant was collected by decantation, and the resulting precipitate was mixed again with 5 volumes of PBS for another $1.5 \mathrm{hr}$ under continuous stirring at $40^{\circ} \mathrm{C}$. After centrifugation, the supernatants were combined, passed through three consecutive membrane filters $(5.0,0.45$ and $0.22 \mu \mathrm{m})$, and stored at $-80^{\circ} \mathrm{C}$ until use. The concentration $(w / v)$ of the extract was calculated by subtracting the weight of lyophilized PBS of the same volume from the weight of the lyophilized PBS extract.

Gel Filtration of Red Bell Pepper Extract The extract of red bell pepper $(2 \mathrm{ml}, 120 \mathrm{mg})$ was applied to a column of Sephadex G-50 $(1.5 \times 30 \mathrm{~cm})$ equilibrated with $\mathrm{PBS}$ and eluted with the same buffer at $4^{\circ} \mathrm{C}$.

Mice — Female BALB/c mice, purchased from Charles River Japan (Yokohama, Japan), and female $\mathrm{C} 3 \mathrm{H} / \mathrm{HeJ}$ mice, obtained from Japan SLC (Hamamatsu, Japan), were housed under specific pathogen-free conditions in the animal facility of Okayama University and used between 8 and 12 weeks of age. Experimental procedures involving mice were carried out in accordance with the guidelines established by the Ministry of Education, Culture, Sports, Science and Technology of Japan and with the Guidelines for Animal Experiments at Okayama University and were approved by the Animal Research Control Committee of Okayama University.

Preparation of Enriched B Cell Population Murine spleen resting conventional $\left(\mathrm{CD}^{-}\right) \mathrm{B}$ cells were enriched by negative selection using a mouse B lymphocyte enrichment set (BD Biosciences Pharmingen) as described previously. $\left.{ }^{8}\right)$ Briefly, murine spleen cells depleted of erythrocytes by lysis with ammonium chloride were suspended in Dulbecco's modified Eagle's medium supplemented with $4 \mathrm{mM}$ L-glutamine, $100 \mathrm{U} / \mathrm{ml}$ penicillin and $100 \mu \mathrm{g} / \mathrm{ml}$ streptomycin and incubated on ice for $60 \mathrm{~min}$ with biotin-conjugated anti-mouse CD4, CD43 and TER-119/erythroid cell mAbs. The cells bearing the biotinylated antibodies were bound to BD IMag streptavidin particles, and negative selection was then performed on a BD IMagnet according to the manufacturer's protocol to enrich unlabeled B cells. The purity of recovered viable B cells ranged between $97 \%$ and $98 \%$ when the cells were stained with fluorescein isothiocyanate (FITC)-conjugated anti-mouse CD45R/B220 mAb and propidium iodide after preincubation of the cells with anti-mouse CD16/CD32 mAb to block $\mathrm{Fc}$-mediated binding of $\mathrm{Ab}$ to the $\mathrm{Fc} \gamma$ receptor of cells and analyzed by a flow cytometer (Epics XL, Beckman Coulter, Miami, FL, U.S.A.). More than 95\% of the cells in the enriched B cell preparations were small resting B cells as judged by the values of forward scatter in flow cytometry.

Antibody Response of Enriched B cells or Erythrocytes-depleted Spleen Cells — B cells enriched from spleen cells or erythrocytes-depleted spleen cells were suspended in basal culture medium (RPMI 1640 medium, supplemented with $10 \%$ heat-inactivated fetal bovine serum, $2 \mathrm{mM} \mathrm{L}-$ glutamine, $100 \mathrm{U} / \mathrm{ml}$ of penicillin $\mathrm{G}$ and $100 \mu \mathrm{g} / \mathrm{ml}$ of streptomycin) and incubated with or without the extract of red bell pepper for 5 days, unless stated otherwise, in round-bottom 96 -well plates $(2.5 \times$ $10^{5}$ cell $/ 200 \mu \mathrm{l}$ per well) at $37^{\circ} \mathrm{C}$ in a fully humidified atmosphere containing $5 \% \mathrm{CO}_{2}$. The culture supernatant was then collected and was frozen at $-30^{\circ} \mathrm{C}$ for an $\operatorname{IgM}$ enzyme-linked immunosorbent assay (ELISA). The IgM levels were assayed by a sandwich ELISA as described previously. ${ }^{9}{ }^{\text {) }}$

Enzyme-linked Immunospot (ELISPOT) Assay — The ELISPOT assay was performed as described previously. ${ }^{10)}$ Briefly, to the 96-well microtiter plate coated with goat anti-mouse IgM Ab, enriched B cells, which had been incubated with or without the extract of red bell pepper for 5 days and washed with and suspended in the basal culture medium, were added $\left(2 \times 10^{3}\right.$ viable cell/200 $\mu \mathrm{l}$ per well) in quintuplicate and incubated for $2 \mathrm{hr}$ at $37^{\circ} \mathrm{C}$. After being washed three times, the plate was incubated with $50 \mu \mathrm{l}$ of HRP-conjugated goat anti- 
mouse $\operatorname{IgM} \mathrm{Ab}(0.2 \mu \mathrm{g} / \mathrm{ml})$ for $1 \mathrm{hr}$ at room temperature. After washing, $100 \mu \mathrm{l}$ of substrate solution consisting of $50 \mathrm{mM}$ sodium phosphate buffer ( $\mathrm{pH} 7.0), 1 \%$ agarose, $2 \mathrm{mg} / \mathrm{ml}$ of diaminobenzidine, $0.0018 \% \mathrm{H}_{2} \mathrm{O}_{2}, 0.0018 \% \mathrm{NiCl}_{2}$, and $0.0018 \%$ $\mathrm{CoCl}_{2}$ was added. The plates were then incubated overnight at $37^{\circ} \mathrm{C}$ in the dark, and the number of spos was counted under a stereomicroscope. The data are expressed as number of spot-forming cells per $2.5 \times 10^{5}$ viable cells harvested.

Measurement of Cell-surface CD138 Expression — Enriched B cells, which had been incubated with or without the extract of red bell pepper for 6 days, were washed with and suspended in PBS containing $0.5 \%$ bovine serum albumin (BSA) and $0.1 \%$ sodium azide (about $1 \times$ $10^{6}$ cell $\left./ 100 \mu \mathrm{l}\right)$. The cells were then incubated with anti-mouse CD16/CD32 mAb $(10 \mu \mathrm{g} / \mathrm{ml})$ for $5 \mathrm{~min}$ on ice and stained with PE-conjugated rat antimouse CD138 mAb $(4 \mu \mathrm{g} / \mathrm{ml})$ for $30 \mathrm{~min}$ on ice. After being washed with and suspended in PBS containing $0.5 \%$ BSA and $0.1 \%$ sodium azide, the cells were stained with propidium iodide $(2 \mu \mathrm{g} / \mathrm{ml})$, and expression of CD138 on viable cells was analyzed by the flow cytometer.

Determination of DNA Synthesis — Enriched B cells, which had been incubated with or without the extract of red bell pepper for $72 \mathrm{hr}$, were pulse-labeled with $\left[{ }^{3} \mathrm{H}\right]$ thymidine $(0.5 \mu \mathrm{Ci} /$ well, $2.5 \mathrm{Ci} / \mathrm{mmol}$ ) for the last $24 \mathrm{hr}$ and harvested on glass fiber filters as described previously. ${ }^{8)}$ The amount of $\left[{ }^{3} \mathrm{H}\right]$ thymidine incorporated was measured in a liquid scintillation counter.

Data Analysis — Results are expressed as means \pm S.E. of three or four independent experiments. Data were analyzed by Student's $t$-test or one-way analysis of variance (ANOVA), followed by Dunnett's $t$-test. $P$ values less than $5 \%$ were regarded as significant.

\section{RESULTS}

\section{Enhancement of IgM Production by the Extract of Red Bell Pepper}

Spleen B cells of BALB/c mice were incubated with or without varying doses of red bell pepper extracts for 5 days and the amount of IgM secreted was determined. The extract dose-dependently increased polyclonal IgM production, the greatest enhancement being $350 \%$ at a concentration of $1.5 \mathrm{mg} / \mathrm{ml}$ (Fig. 1A). IgM production in whole
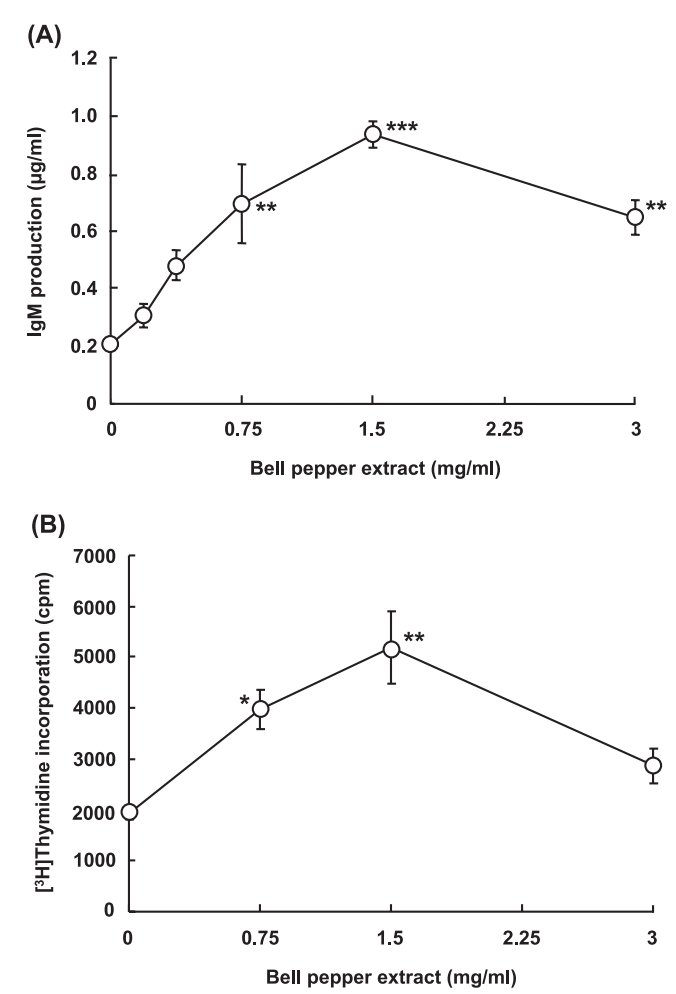

Fig. 1. Enhancement of IgM Production in B Cells by the Extract of Red Bell Pepper

$B$ cells of $B A L B / c$ mice were incubated with or without the indicated doses of red bell pepper extract. (A) IgM in the supernatants of 5-day culture was measured by an ELISA. (B) B cells were labeled with $\left[{ }^{3} \mathrm{H}\right]$ thymidine for the last $24 \mathrm{hr}(48-72 \mathrm{hr})$. The data are means \pm S.E. of three independent experiments each of which had three determinations. ${ }^{*} p<0.05,{ }^{* *} p<0.01,{ }^{* * *} p<0.001$, as compared with the control (Dunnett's $t$-test).

spleen cells was similarly promoted by the extract (data not shown). Figure 1B shows the effect of the extract on proliferation of B cells. B cells were incubated with or without the extract for $72 \mathrm{hr}$ and labeled with $\left[{ }^{3} \mathrm{H}\right]$ thymidine for the last $24 \mathrm{hr}$. The extract significantly increased $\left[{ }^{3} \mathrm{H}\right]$ thymidine incorporation of cells, indicating that it augmented B cell proliferation.

Enhancement of IgM Production in B Cells Treated with Polymyxin B or Lipopolysaccharide (LPS)-unresponsive Spleen Cells by the Red Bell Pepper Extract

Since red bell pepper is cultivated in a field, there is a possibility that the extract of bell pepper is contaminated with an endotoxin such as LPS. In order to exclude this possibility, we did two experiments: treatment of the extract with polymyxin $\mathrm{B}$, which binds and inactivates LPS, ${ }^{11)}$ and an experiment using LPS-unresponsive spleen cells of $\mathrm{C} 3 \mathrm{H} / \mathrm{HeJ}$ mice lacking a functional Toll-like recep- 
(A)
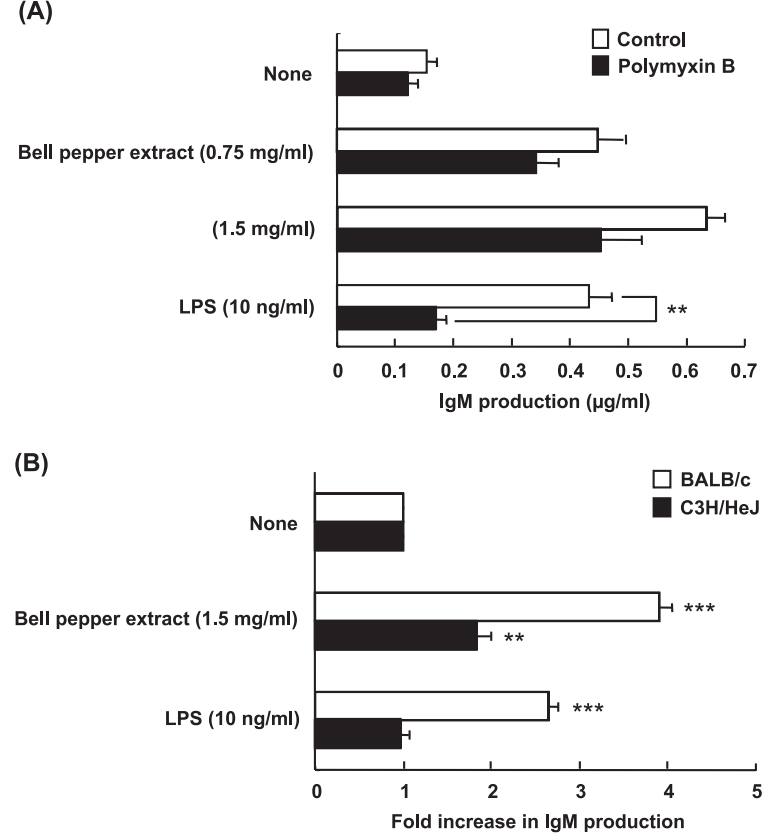

Fig. 2. Enhancement of IgM Production in B Cells Treated with Polymyxin B or LPS-unresponsive Spleen Cells by the Extract of Red Bell Pepper

(A) B cells of BALB/c mice were cultured for 5 days with or without the extract of red bell pepper preincubated with or without polymyxin B $(5 \mu \mathrm{g} / \mathrm{ml})$. (B) Spleen cells of $\mathrm{C} 3 \mathrm{H} / \mathrm{HeJ}$ mice and BALB/c mice were cultured for 5 days with or without the extract of red bell pepper. IgM in the culture supernatants was measured by an ELISA. The data are means \pm S.E. of three independent experiments each of which had three determinations. ${ }^{* *} p<0.01,{ }^{* * *} p<0.001$, as compared with each control (A, Student's $t$-test) or with the control of each strain (B, Dunnett's $t$-test).

tor 4 (TLR4). ${ }^{12)}$ The extract or LPS was preincubated with polymyxin $\mathrm{B}$ for $15 \mathrm{~min}$ at $37^{\circ} \mathrm{C}$ before being added to the $\mathrm{B}$ cells of $\mathrm{BALB} / \mathrm{c}$ mice. $\operatorname{IgM}$ production induced by the extract was not significantly inhibited by polymyxin B, which completely abrogated the enhancing effect of LPS (Fig. 2A). The extract of red bell pepper but not LPS significantly increased IgM production by spleen cells of $\mathrm{C} 3 \mathrm{H} / \mathrm{HeJ}$ mice, although the promoting potency of the extract observed in $\mathrm{C} 3 \mathrm{H} / \mathrm{HeJ}$ spleen cells was less than that observed in BALB/c spleen cells (Fig. 2B).

\section{Differentiation of B Cells by the Extract of Red Bell Pepper}

In order to confirm enhanced differentiation of $B$ cells treated with the extract of red bell pepper, the number of antibody-secreting cells in cultures of B cells from BALB/c mice treated with or without the extract for 5 days was determined by the ELISPOT assay, and the results are expressed as number of spots per $2.5 \times 10^{5}$ viable cells harvested. Treat-
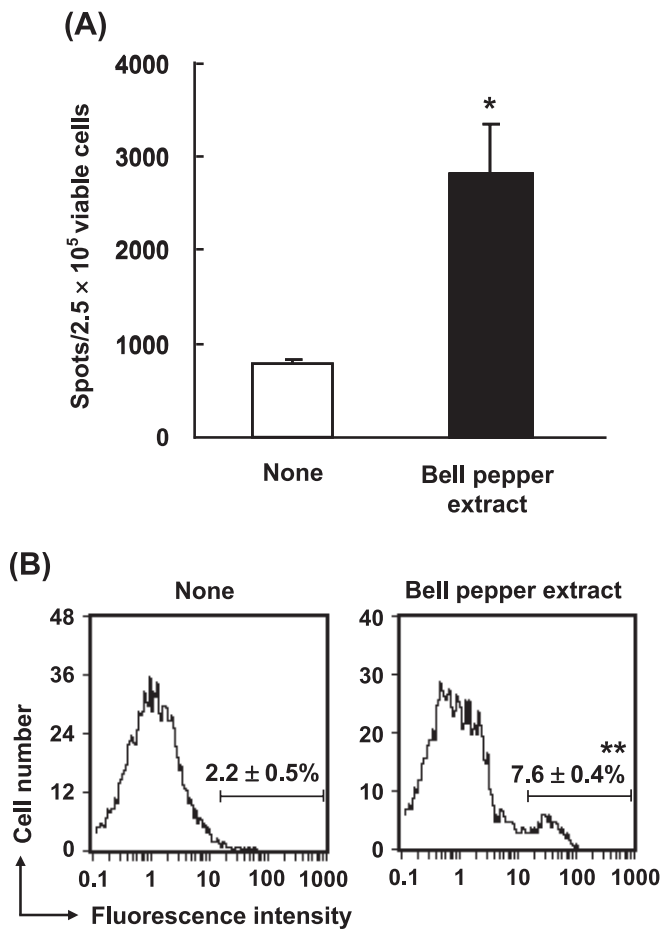

Fig. 3. Increase Induced by the Red Bell Pepper Extract in the Number of IgM-secreting Cells and CD138 ${ }^{+}$Cells

$B$ cells of $B A L B / c$ mice were incubated with or without the extract of red bell pepper $(1.5 \mathrm{mg} / \mathrm{ml})$ for 5 days (A) or 6 days (B). (A) The number of IgM-secreting cells was measured by an ELISPOT assay. (B) The cells were stained with PE-conjugated anti-CD138 mAb and analyzed by the flow cytometer. The data are means \pm S.E. of four (A) and three (B) independent experiments which had five and one determinations, respectively. Histograms (B) are representative of three independent experiments. ${ }^{*} p<0.05,{ }^{* *} p<0.01$, as compared with the control (Student's $t$-test).

ment with the extract resulted in $250 \%$ increase in the number of IgM-secreting cells (Fig. 3A). It is known that differentiation of naive $\mathrm{B}$ cells to plasma cells is accompanied by an increase in CD138 expression. ${ }^{13)} \mathrm{B}$ cells of BALB/c mice treated with or without the extract for 6 days were subjected to analysis of expression of the cell-surface antigen by a flow cytometer. The extract significantly increased the population of $\mathrm{CD} 138^{+}$cells (Fig. 3B).

\section{Properties of an Active Substance(s) in the Ex- tract of Red Bell Pepper}

The extract was subjected to gel filtration to determine the molecular weight of a substance(s) with activity for enhancement of IgM production. The activity was eluted in a peak with an apparent molecular weight of about 6000 (Fig. 4A). The IgM production-inducing activity in the extract of red bell pepper was almost completely and completely inactivated by being incubated for $10 \mathrm{~min}$ at $80^{\circ} \mathrm{C}$ and $100^{\circ} \mathrm{C}$, respectively (Fig. 4B). The activity in 


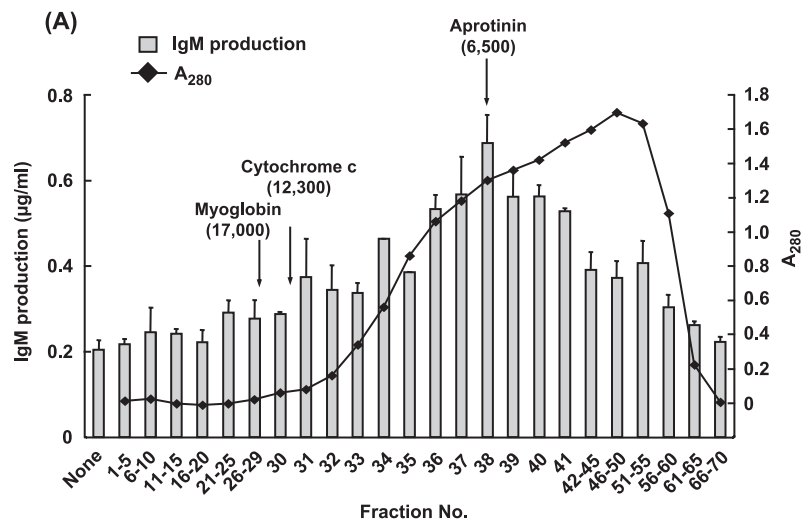

(B)

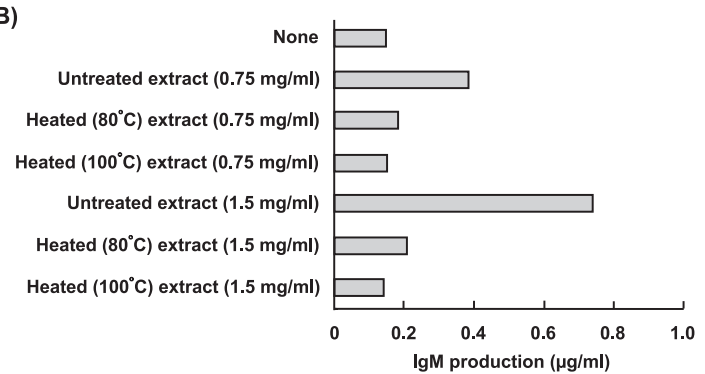

Fig. 4. Gel Filtration Profile and Inactivation by Heating of IgM Production-enhancing Activity of Red Bell Pepper Extract

(A) Two $\mathrm{ml}(120 \mathrm{mg})$ of red bell pepper extract was applied to a Sephadex G-50 column, and 1-ml fractions were collected. Spleen cells of BALB/c mice were incubated for 5 days with or without $10 \%$ of each fraction. IgM in the culture supernatants was measured by an ELISA. Molecular weight markers used were myoglobin (17000), cytochrome c (12300), and aprotinin (6500). The data are representative of two independent experiments with similar results and expressed as means \pm S.E. of triplicate cultures. (B) The extract of red bell pepper $(60 \mathrm{mg} / \mathrm{ml})$ was incubated for $10 \mathrm{~min}$ at $80^{\circ} \mathrm{C}$ and $100^{\circ} \mathrm{C}$ and centrifuged. Spleen cells of BALB/c mice were incubated for 5 days with or without the treated and untreated extracts. IgM in the culture supernatants was measured by an ELISA. The data are means of two independent experiments.

the extract was not inactivated by being treated with $0.01 \%$ trypsin for $30 \mathrm{~min}$ at $37^{\circ} \mathrm{C}$ (data not shown).

\section{DISCUSSION}

Our results presented here demonstrated that the extract of red bell pepper promoted proliferation and differentiation of $\mathrm{B}$ cells: the extract increased DNA synthesis in B cells and increased the number of IgM-secreting cells and CD138 ${ }^{+}$cells, resulting in enhancement of IgM production. Similar enhancement of IgM production in both B cells and whole spleen cells suggests that functions of T cells and macrophages are marginally, if any, influenced by the extract. The extract of red bell pepper showed bell-shaped dose-responses for both IgM production and proliferation of B cells, suggesting that the extract also contains an inhibitory substance(s) which is effective at higher concentrations.

Our data in Fig. 2 indicated that polymyxin B did not affect the activity of the red bell pepper extract, whereas the extract had a smaller but significant enhancing effect on IgM production in $\mathrm{B}$ cells of $\mathrm{C} 3 \mathrm{H} / \mathrm{HeJ}$ mice than on $\mathrm{IgM}$ production in $\mathrm{B}$ cells of $\mathrm{BALB} / \mathrm{c}$ mice. Kim et al. have reported substances with similar properties: polysaccharides isolated from Acanthopanax senticosus and Acanthopanax koreanum potently activated B cells of $\mathrm{C} 3 \mathrm{H} / \mathrm{HeN}$ mice but much less potently activated $\mathrm{B}$ cells of $\mathrm{C} 3 \mathrm{H} / \mathrm{HeJ}$ mice, and the activity of the polysaccharides was resistant to polymyxin $\mathrm{B} .{ }^{14,15)}$ These results suggest that the effect of red bell pepper extract is not due to, if any, contaminating LPS in the preparation and that both mechanisms involving and not involving TLR4 are responsible for the effects of the extract. A considerable number of potential agonists of non-microbial origin have been reported to activate the TLR4 pathway. They include fibronectin, hyaluronan oligosaccharides, fibrinogen, amyloid A, and ceramide. ${ }^{16,17)}$ TLR4 agonists derived from plants such as Taxol and G14A, an acidic polysaccharide, have also been reported. ${ }^{18,19)}$

The IgM production-enhancing activity in the extract of red bell pepper was resistant to trypsin treatment but was heat-labile. Although most plants produce proteinase inhibitors as a defense against insects and pathogenic organisms, the azocaseinolytic activity of trypsin was only slightly inhibited by the extract (our unpublished results). The results of gel filtration of the extract indicated that the IgM production-inducing activity was eluted in fractions of high molecular weight. Therefore, the active substance(s) in the extract seems to be a nonproteinous heat-labile macromolecule.

Bell peppers are popular vegetables that are cultivated throughout the world and have the advantage of being safe and easy to take. Our results suggest that red bell pepper may be useful for upregulating antibody production and thus may help in combating infections, although its in vivo effects remain to be tested.

\section{REFERENCES}

1) Grubeck-Loebenstein, B. (1997) Changes in the aging immune system. Biologicals, 25, 205-208. 
2) Wustrow, T. P. and Mahnke, C. G. (1996) Causes of immunosuppression in squamous cell carcinoma of the head and neck. Anticancer Res., 16, 2433-2468.

3) Aubin, F. (2003) Mechanisms involved in ultraviolet light-induced immunosuppression. Eur. J. Dermatol., 13, 515-523.

4) Marín, A., Ferreres, F., Tomás-Barberán, F. A. and Gil, M. I. (2004) Characterization and quantitation of antioxidant constituents of sweet paper (Capsicum annuum L.). J. Agric. Food Chem., 52, 38613869.

5) El Hamss, R., Idaomar, M., Alonso-Moraga, A. and Muñoz-Serrano, A. (2003) Antimutagenic properties of bell and black peppers. Food Chem. Toxicol., 41, 41-47.

6) Narisawa, T., Fukaura, Y., Hasebe, M., Nomura, S., Oshima, S. and Inakuma, T. (2000) Prevention of $\mathrm{N}$-methylnitrosourea-induced colon carcinogenesis in rats by oxygenated carotenoid capsanthin and capsanthin-rich paprika juice. Proc. Soc. Exp. Biol. Med., 224, 116-122.

7) Sancho, R., Lucera, C., Macho, A., Calzado, M. A., Blanco-Molina, M., Minassi, A., Appendino, G. and Muñnoz, E. (2002) Immunosuppressive activity of capsaicinoids: capsiate derived from sweet peppers inhibits NF- $\kappa \mathrm{B}$ activation and is a potent antiinflammatory compound in vivo. Eur. J. Immunol., 32, 1753-1763.

8) Aoyama, E., Yoshihara, R., Tai, A., Yamamoto, I. and Gohda, E. (2005) PKC- and PI3K-dependent but ERK-independent proliferation of murine splenic B cells stimulated by chondroitin sulfate B. Immunol. Lett., 99, 80-84.

9) Kawamoto, T., Gohda, E., Iji, H., Fujiwara, M. and Yamamoto, I. (1998) SKW 6.4 cell differentiation induced by interleukin 6 is stimulated by butyrate. Immunopharmacology, 40, 119-130.

10) Yoshihara, R., Aoyama, E., Kadota, Y., Kawai, S., Goto, T., Zhong, M. and Gohda, E. (2007) Differentiation of murine B cells induced by chondroitin sulfate B. Cell. Immunol., 250, 14-23.

11) Storm, D. R., Rosenthal, K. S. and Swanson, P. E. (1977) Polymyxin and related peptide antibiotics. Annu. Rev. Biochem., 46, 723-763.
12) Poltorak, A., He, X., Smirnova, I., Liu, M. Y., Van Huffel, C., Du, X., Birdwell, D., Alejos, E., Silva, M., Galanos, C., Freudenberg, M., RicciardiCastagnoli, P., Layton, B. and Beutler, B. (1998) Defective LPS signaling in $\mathrm{C} 3 \mathrm{H} / \mathrm{HeJ}$ and $\mathrm{C} 57 \mathrm{BL} /$ 10ScCr mice: mutations in Tlr4 gene. Science, 282, 2085-2088.

13) Sanderson, R. D., Lalor, P. and Bernfield, M. (1989) B lymphocytes express and lose syndecan at specific stages of differentiation. Cell Regul., 1, 27-35.

14) Han, S. B., Park, S. K., Ahn, H. J., Yoon, Y. D., Kim, Y. H., Lee, J. J., Lee, K. H., Moon, J. S., Kim, H. C. and Kim, H. M. (2003) Characterization of $\mathrm{B}$ cell membrane receptors of polysaccharide isolated from the root of Acanthopanax koreanum. Int. Immunopharmacol., 3, 683-691.

15) Han, S. B., Yoon, Y. D., Ahn, H. J., Lee, H. S., Lee, C. W., Yoon, W. K., Park, S. K. and Kim, H. M. (2003) Toll-like receptor-mediated activation of B cells and macrophages by polysaccharide isolated from cell culture of Acanthopanax senticosus. Int. Immunopharmacol., 3, 1301-1312.

16) Wakelin, S. J., Sabroe, I., Gregory, C. D., Poxton, I. R., Forsythe, J. L. R., Garden, O. J. and Howie, S. E. M. (2006) "Dirty little secrets"Endotoxin contamination of recombinant proteins. Immunol. Lett., 106, 1-7.

17) Fischer, H., Ellström, P., Ekström, K., Gustafsson, L., Gustafsson, M. and Svanborg, C. (2007) Ceramide as a TLR4 agonist; a putative signaling intermediate between sphingolipid receptors for microbial ligands and TLR4. Cell. Microbiol., 9, 12391251.

18) Kawasaki, K., Akashi, S., Shimizu, R., Yoshida, T., Miyake, K. and Nishijima, M. (2000) Mouse toll-like receptor $4 \cdot \mathrm{MD}-2$ complex mediates lipopolysaccharide-mimetic signal transduction by Taxol. J. Biol. Chem., 275, 2251-2254.

19) Raghu, R., Sharma, D., Ramakrishnan, R., Khanam, S., Chintalwar, G. J. and Sainis, K. B. (2009) Molecular events in the activation of B cells and macrophages by a non-microbial TLR4 agonist, G14A form Tinospora cordifolia. Immunol. Lett., 123, 60-71. 